\title{
Campylobacter mucosalis (Lawson, Leaver, Pettigrew, and Rowland 1981) comb. nov.: Emended Description
}

\author{
R. MARTIN ROOP II, ${ }^{1}$ R. M. SMIBERT, ${ }^{2}$ JOHN L. JOHNSON, ${ }^{2}$ AND NOEL R. KRIEG ${ }^{1 *}$ \\ Department of Biology (Microbiology Section) ${ }^{1}$ and Department of Anaerobic Microbiology, ${ }^{2}$ Virginia Polytechnic \\ Institute and State University, Blacksburg, Virginia 24061
}

\begin{abstract}
Seven strains of Campylobacter sputorum subsp. mucosalis, reference strains of Campylobacter fetus, Campylobacter jejuni, Campylobacter coli, Campylobacter laridis, "Campylobacter hyointestinalis," "Campylobacter fecalis," C. sputorum subsp. sputorum, C. sputorum subsp. bubulus, and Campylobacter nitrofigilis, aerotolerant Campylobacter sp. strain 02790, and catalase-negative or weakly catalase-positive strain CG-1 were compared with $C$. sputorum subsp. mucosalis type strain NCTC 11000 in deoxyribonucleic acid hybridization experiments. Strain NCTC $11000^{\mathrm{T}}(\mathrm{T}=$ type strain) showed a high level of deoxyribonucleic acid homology with all of the $C$. sputorum subsp. mucosalis strains tested, but no significant homology with any of the other reference strains used, including $C$. sputorum subsp. sputorum and $C$. sputorum subsp. bubulus strains. Based on these observations, we propose that $C$. sputorum subsp. mucosalis be reclassified as Campylobacter mucosalis comb. nov.
\end{abstract}

In 1974, Lawson and Rowland isolated microaerophilic, gram-negative, curved bacteria from the lesions of porcine intestinal adenomatosis. These organisms resembled Campylobacter sputorum in their morphological and phenotypic characteristics and were given the name Campylobacter sputorum subsp. mucosalis $(7,8)$. C. sputorum subsp. mucosalis differs from $C$. sputorum subsp. sputorum and $C$. sputorum subsp. bubulus in two respects. First, C. sputorum subsp. mucosalis requires either $\mathrm{H}_{2}$ or formate as an electron donor for microaerophilic or anaerobic growth (7), whereas $C$. sputorum subsp. sputorum and $C$. sputorum subsp. bubulus grow under either microaerophilic or anaerobic conditions without $\mathrm{H}_{2}$ or formate. However, growth of $C$. sputorum subsp. sputorum and $C$. sputorum subsp. bubulus may be enhanced by these compounds (21). Second, the deoxyribonucleic acid (DNA) base composition reported for $C$. sputorum subsp. mucosalis is $34 \mathrm{~mol} \%$ guanine plus cytosine $(G+C)(7)$, compared with 30 to $32 \mathrm{~mol} \% \mathrm{G}+\mathrm{C}$ reported for $C$. sputorum subsp. sputorum and $C$. sputorum subsp. bubulus (21).

The purpose of this study was to determine the relationship between $C$. sputorum subsp. mucosalis and $C$. sputorum subsp. sputorum, C. sputorum subsp. bubulus, and reference strains of other recognized Campylobacter species by means of DNA hybridization experiments.

\section{MATERIALS AND METHODS}

Organisms. The origins of all of the strains used in this study are shown in Table 1 . In all but three cases the type strains were included. In the case of $C$. sputorum subsp. sputorum, type strain ER-33 (10) is no longer extant; therefore, strain VPI S-17 was used as the reference strain in this study. This strain fits the original description of the species (10) and has been used by other investigators as a reference strain for $C$. sputorum subsp. sputorum $(5,22)$. In the cases of "Campylobacter hyointestinalis" (3) and "Campylobacterfecalis" (2) type strains have not been designated, and the strains used were the reference strains suggested by the authors who proposed these names.

Growth conditions. Stock cultures of $C$. sputorum subsp. mucosalis and Campylobacter concisus were maintained in

\footnotetext{
* Corresponding author.
}

semisolid brucella medium supplemented with $0.3 \%$ fumaric acid and $0.16 \%$ agar (semisolid BF medium) and adjusted to $\mathrm{pH} 7.0$ with $\mathrm{KOH}$. Cultures were incubated under an atmosphere containing $6 \% \mathrm{O}_{2}, 5 \% \mathrm{CO}_{2}, 15 \% \mathrm{H}_{2}$, and $74 \% \mathrm{~N}_{2}$. Stock cultures of other campylobacters were maintained in semisolid brucella medium containing $0.16 \%$ agar incubated aerobically. Semisolid brucella medium was supplemented with $1.0 \% \mathrm{NaCl}$ for growth of Campylobacter nitrofigilis (14). All stock cultures except $C$. nitrofigilis and aerotolerant Campylobacter sp. strain 02790 stock cultures were incubated at $37^{\circ} \mathrm{C} ; C$. nitrofigilis and aerotolerant Campylobacter sp. strain 02790 stock cultures (16) were incubated at $30^{\circ} \mathrm{C}$. Stock cultures were transferred weekly and also stored in liquid nitrogen.

For DNA isolation, $C$. sputorum subsp. mucosalis strains were inoculated into semisolid $\mathrm{BF}$ medium and incubated at $37^{\circ} \mathrm{C}$ under an atmosphere containing $6 \% \mathrm{O}_{2}, 5 \% \mathrm{CO}_{2}, 15 \%$ $\mathrm{H}_{2}$, and $74 \% \mathrm{~N}_{2}$. After $48 \mathrm{~h}$, the top 1 to $2 \mathrm{ml}$ of growth from two tubes was used to inoculate a Roux bottle containing a diphasic medium $(200 \mathrm{ml}$ of BF medium supplemented with $0.2 \%$ sodium formate and solidified with $2.5 \%$ agar, overlaid with $50 \mathrm{ml}$ of BF medium broth supplemented with $0.2 \%$ sodium formate). These cultures were incubated aerobically at $37^{\circ} \mathrm{C}$ for 24 to $48 \mathrm{~h}$. The growth from eight Roux bottles was usually sufficient to yield enough DNA for the experiments. Strain CG-1, which was obtained from C. Gebhart and is an unclassified, catalase-negative or weakly catalasepositive strain similar to the strains described by Sandstedt et al. (19), was grown under similar conditions; however, ferrous-bisulfite-pyruvate medium (4) was used in the Roux bottles instead of BF medium supplemented with $0.2 \%$ sodium formate. C. sputorum strains were grown in Roux bottles containing BF medium as described above, and the growth from two bottles was used to inoculate 1 liter of $\mathrm{BF}$ medium broth in a 2-liter Erlenmeyer flask. These cultures were incubated aerobically with shaking at $37^{\circ} \mathrm{C}$ for $24 \mathrm{~h}$. The growth conditions used for all of the catalase-positive campylobacters except $C$. nitrofigilis have been described previously (18). C. nitrofigilis was grown in the same way as the other catalase-positive strains, except that all media were supplemented with $1.0 \% \mathrm{NaCl}$ (14). All cultures were checked for purity by phase-contrast microscopy prior to harvesting. 
TABLE 1. Bacterial strains used in this study

\begin{tabular}{|c|c|c|c|}
\hline Taxon & Strain & Source ${ }^{a}$ & Origin \\
\hline C. sputorum & NCTC $11000^{\mathrm{T}}$ & Lawson & Porcine \\
\hline subsp. & $79-12009$ & Ward & Porcine \\
\hline mucosalis & P-9681C & Hayes & Porcine \\
\hline & P-10546C & Hayes & Porcine \\
\hline & P-5007 & Hayes & Porcine \\
\hline & P-11508 & Hayes & Porcine \\
\hline & P-5494 & Hayes & Porcine \\
\hline & P-10742 & Hayes & Porcine \\
\hline $\begin{array}{l}\text { C. sputorum } \\
\text { subsp. } \\
\text { sputorum }\end{array}$ & VPI S-17 & Smibert & Human \\
\hline $\begin{array}{l}\text { C. sputorum } \\
\text { subsp. } \\
\text { bubulus }\end{array}$ & $\operatorname{ATCC} 33562^{\mathrm{T}}$ & ATCC & Bovine \\
\hline "C. fecalis" & $\begin{array}{l}11363 \\
(=\text { ATCC 33709) }\end{array}$ & Firehammer & Ovine \\
\hline C. concisus & ATCC $33237^{\mathrm{T}}$ & Tanner & Human \\
\hline $\begin{array}{l}\text { C. fetus } \\
\text { subsp. } \\
\text { fetus }\end{array}$ & ATCC $27374^{\mathrm{T}}$ & ATCC & Ovine \\
\hline $\begin{array}{l}\text { C. fetus } \\
\text { subsp. } \\
\text { venerealis }\end{array}$ & ATCC $19438^{\mathrm{T}}$ & ATCC & Bovine \\
\hline C. jejuni & ATCC $33560^{\mathrm{T}}$ & ATCC & Bovine \\
\hline C. coli & ATCC $33559^{\mathrm{T}}$ & ATCC & Porcine \\
\hline C. laridis & NCTC $11352^{\mathrm{T}}$ & NCTC & Avian \\
\hline $\begin{array}{l}\text { "C. hyo- } \\
\text { intestinalis" }\end{array}$ & $\begin{array}{l}80-4577-4 \\
\quad(=\text { ATCC 35217) }\end{array}$ & Gebhart & Porcine \\
\hline C. nitrofigilis & ATCC $33309^{\mathrm{T}}$ & ATCC & $\begin{array}{c}\text { Spartina } \\
\text { alterni- } \\
\text { flora } \\
\text { roots }\end{array}$ \\
\hline $\begin{array}{l}\text { Catalase- } \\
\text { negative or } \\
\text { weakly } \\
\text { catalase- } \\
\text { positive } \\
\text { campylobacters }\end{array}$ & $\mathrm{CG}-1$ & Gebhart & Canine \\
\hline $\begin{array}{l}\text { Aerotolerant } \\
\text { campylobacters }\end{array}$ & 02790 & Neill & Porcine \\
\hline
\end{tabular}

(Dick) School of Veterinary Studies, Ward, Veterinary Diagnostic Laboratory, University of Minnesota. St. Paul: Hayes. J. Hayes, Purdue University School of Veterinary Medicine, West Lafayette, Ind.; Smibert, R. M. Smibert, Department of Anaerobic Microbiology, Virginia Polytechnic Institute and State University, Blacksburg; ATCC, American Type Culture Collection, Rockville, Md.; Firehammer, B. D. Firehammer, Veterinary Research Laboratory, Montana State University, Bozeman: Tanner, A. C. R. Tanner. Forsyth Dental Center, Boston, Mass. NCTC, National Collection of Type Cultures, London, England: Gebhart, C. Gebhart, Veterinary Diagnotic Laboratory, University of Minnesota, St. Paul; Neill, S. D. Neill, Veterinary Research Laboratory, Belfast, Ireland.

${ }^{b}$ Suggested type strain (B. D. Firehammer, personal communication).

c Suggested type strain (C. Gebhart, personal communication).

DNA isolation, DNA homology experiments, and determination of DNA base composition. DNA was extracted and purified by the hydroxylapatite procedure described by Johnson (6). The $S 1$ nuclease procedure described by Johnson (6) was used for the DNA homology experiments, and the homology experiments were performed under "optimal", conditions (i.e., $25^{\circ} \mathrm{C}$ below the thermal melting point of the DNA [12]). DNA from $C$. sputorum subsp. mucosalis NCTC $11000^{\mathrm{T}}\left(\mathrm{T}=\right.$ type strain) was labeled in vitro with ${ }^{125} \mathrm{I}$ by using the method of Selin et al. (20).

The thermal melting points of the DNAs from $C$. sputorum subsp. mucosalis strains NCTC $11000^{\mathrm{T}}$ and 79-12009 were determined by using the method described by Johnson (6), and the $\mathrm{G}+\mathrm{C}$ contents were determined by using the equation of Mandel et al. (11). DNA from Escherichia coli strain b, which has a $\mathrm{G}+\mathrm{C}$ content of $51 \mathrm{~mol} \%$, was used as a reference.

Physiological characteristics. The procedures used for determining growth in $1 \%$ oxgall, $3.5 \% \mathrm{NaCl}, 1 \%$ glycine, and minimal medium, for determining $\mathrm{H}_{2} \mathrm{~S}$ production in sulfideindole motility medium, from cysteine (lead acetate strips), and on triple sugar iron agar slants, for determining growth at 25 and $42^{\circ} \mathrm{C}$, and for determining susceptibility to nalidixic acid and cephalothin have been described previously (18). Nitrate reduction and nitrite reduction were tested as previously described (18), except that the final concentration of $\mathrm{KNO}_{3}$ in the medium was 0.7 instead of $1.0 \%$. Deoxyribonuclease activity and the ability to grow on $1.5 \% \mathrm{NaCl}$ plates were tested as previously described (18), except that the basal medium was replaced with brucella agar supplemented with $0.3 \%$ fumaric acid ( $\mathrm{pH} 7.0$ ). In all of the tests mentioned above, cultures were incubated under an atmosphere containing $6 \% \mathrm{O}_{2}, 5 \% \mathrm{CO}_{2}, 15 \% \mathrm{H}_{2}$, and $74 \% \mathrm{~N}_{2}$.

Catalase activity, oxidase activity, hippurate hydrolysis, and anaerobic growth in $0.1 \%$ trimethylamine- $N$-oxide were tested as previously described (18).

\section{RESULTS AND DISCUSSION}

All seven strains of $C$. sputorum subsp. mucosalis used in this study showed a high level of DNA homology ( $\geq 92 \%)$ with the type strain of $C$. sputorum subsp. mucosalis (strain NCTC 11000) but no significant homology with any of the other reference strains tested, including the reference strain

TABLE 2. Levels of DNA homology of $C$. sputorum subsp. mucosalis strains and Campylobacter reference strains with $C$. sputorum subsp. mucosalis NCTC $11000^{\mathrm{T}}$

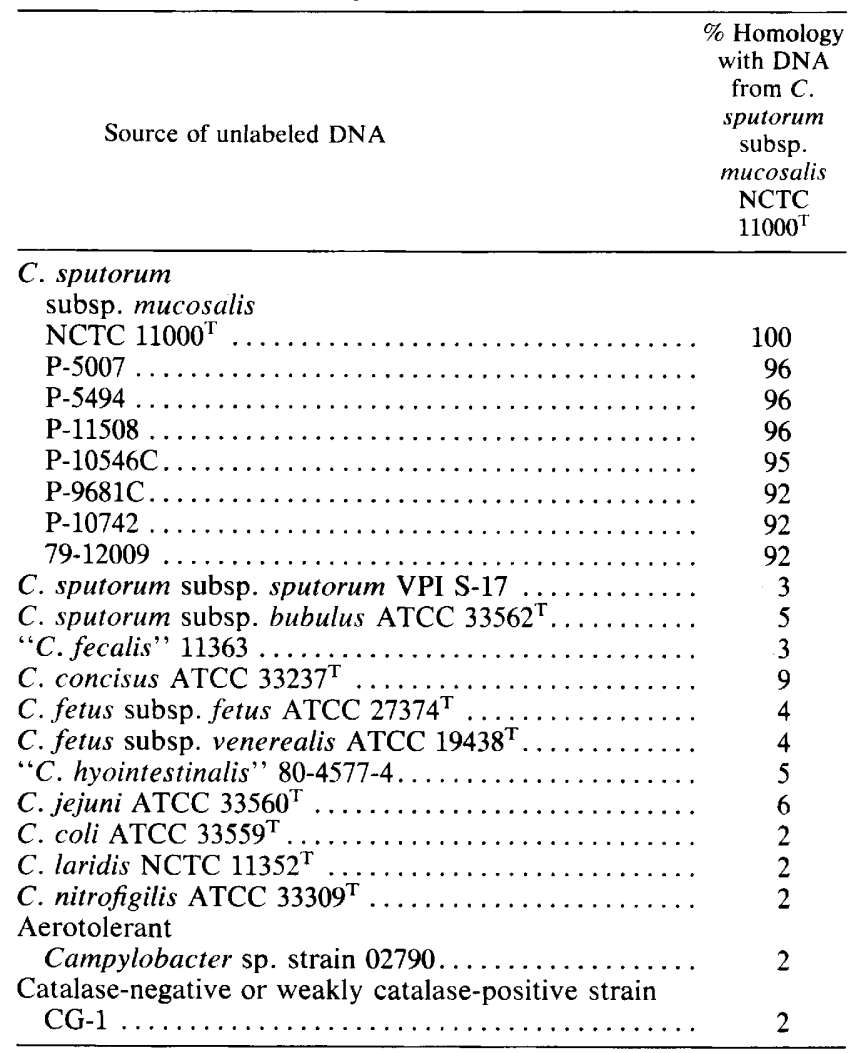


of $C$. sputorum subsp. sputorum (strain VPI S-17) and the type strain of $C$. sputorum subsp. bubulus (strain ATCC 33562) (Table 2).

The base compositions of the DNAs from C. sputorum subsp. mucosalis strains 79-12009 and NCTC $11000^{\mathrm{T}}$ were 38 and $39 \mathrm{~mol} \% \mathrm{G}+\mathrm{C}$, respectively; these values are higher than the value of $34 \mathrm{~mol} \% \mathrm{G}+\mathrm{C}$ reported for strain NCTC $11000^{\mathrm{T}}$ by Lawson et al. (7). The difference may be attributable in part to the use of different equations for calculating the base compositions of the DNAs. The equation of Mandel et al. (11) was used for determining the values given in this paper, whereas the equation of Marmur and Doty (13) was used by Lawson et al. When the $\mathrm{G}+\mathrm{C}$ values for strains 79-12009 and NCTC $11000^{\mathrm{T}}$ were recalculated by using the equation of Marmur and Doty, values of 36 and 37 mol\% were obtained; these values are still higher than the value reported by Lawson et al. (7). The reason for the discrepancy is not known; however, our results are consistent with the value of $38 \mathrm{~mol} \% \mathrm{G}+\mathrm{C}$ obtained for strain NCTC $11000^{\mathrm{T}}$ by Owen and Leaper (17), using the buoyant density method.

C. sputorum subsp. mucosalis strains can be distinguished from all other catalase-negative Campylobacter species except $C$. concisus (22) by their requirement for $\mathrm{H}_{2}$ or formate for microaerophilic growth and $\mathrm{H}_{2}$ and fumarate or formate and fumarate for anaerobic growth (21). Although $C$. concisus strains are similar to $C$. sputorum subsp. mucosalis in their phenotypic characteristics $(21,22)$, they have only a very low level of DNA homology with $C$. sputorum subsp. mucosalis NCTC $11000^{\mathrm{T}}$ (Table 2). C. sputorum subsp. mucosalis strains can be distinguished from $C$. concisus strains by their susceptibility to cephalothin, by their ability to grow at $25^{\circ} \mathrm{C}$, and by the "dirty yellow" color of their colonies (21). The color is best seen when a colony is picked and smeared on a piece of white paper (9).

Growth in a medium containing $1.5 \% \mathrm{NaCl}$ and the inability to grow in the presence of $1 \%$ glycine were reported by Lawson et al. (7) to be characteristics of $C$. sputorum subsp. mucosalis. During the course of the study described in this paper, we found that all eight of the strains tested, including the type strain (strain NCTC 11000), were able to grow in the presence of $1 \%$ glycine. We performed this test in a semisolid medium, which is probably the method that is used in most diagnostic laboratories because of its ease of inoculation and easy interpretation of results. Lawson and Rowland (9) inoculated agar plates containing $1 \%$ glycine with a velour pad that had been charged with inocula from a blood agar plate; they also used a shorter incubation period $(24$ to $48 \mathrm{~h}$ ) than the 4- to 5-day incubation period which we used. In addition, we found that only three of eight $C$. sputorum subsp. mucosalis strains used in our study grew on $1.5 \% \mathrm{NaCl}$ agar plates, and those grew very scantily. This may have been due to differences in the basal media or the methodology used for inoculating the plates. Oxoid blood agar base no. 2 was used as the basal medium by Lawson and Rowland (9), whereas BF medium agar was used in our study. The $\mathrm{NaCl}$ agar plates used in our study were inoculated by continuous streaking with a loop needle with inocula from a 24- to 48-h-old semisolid culture, whereas Lawson and Rowland (9) inoculated $\mathrm{NaCl}$ agar plates in the same manner as glycine agar plates. We believe that our method is the more sensitive of the two for determining ability to grow in $1.5 \% \mathrm{NaCl}$. For instance, growth in $1.5 \%$ $\mathrm{NaCl}$ is an important differential characteristic for Campylobacter laridis $(1,18)$, and those strains which we have tested grow well when our method is used.

The description of $C$. sputorum subsp. mucosalis given in
TABLE 3. Phenotypic characteristics of $C$. mucosalis

\begin{tabular}{|c|c|c|}
\hline \multirow[b]{2}{*}{ Characteristic } & \multicolumn{2}{|c|}{ Reaction of: } \\
\hline & $\begin{array}{c}\text { Strain NCTC } \\
11000^{\mathrm{T}}\end{array}$ & $\begin{array}{c}\text { Seven } \\
\text { other strains }\end{array}$ \\
\hline Catalase & - & $-a$ \\
\hline Oxidase & + & + \\
\hline Nitrate reduction & + & + \\
\hline Nitrite reduction & $-b$ & $\mathrm{~d}^{b}$ \\
\hline \multicolumn{3}{|l|}{ Growth in: } \\
\hline $1 \%$ Oxgall & + & + \\
\hline $1.5 \% \mathrm{NaCl}$ (plates) & - & - \\
\hline $3.5 \% \mathrm{NaCl}$ & - & - \\
\hline $1 \%$ Glycine & + & + \\
\hline Minimal medium ${ }^{c}$ & - & - \\
\hline $\begin{array}{l}\text { Anaerobic growth in } 0.1 \% \\
\text { trimethylamine- } N \text {-oxide }\end{array}$ & - & - \\
\hline \multicolumn{3}{|l|}{$\mathrm{H}_{2} \mathrm{~S}$ production: } \\
\hline $\begin{array}{l}\text { Sulfide-indole motility } \\
\text { medium }\end{array}$ & + & + \\
\hline Lead acetate strips & + & + \\
\hline Triple sugar iron agar & + & + \\
\hline \multicolumn{3}{|l|}{ Growth at: } \\
\hline $25^{\circ} \mathrm{C}$ & + & + \\
\hline $42^{\circ} \mathrm{C}$ & + & + \\
\hline Hippurate hydrolysis & - & - \\
\hline $\begin{array}{l}\text { Deoxyribonuclease } \\
\text { activity }\end{array}$ & - & {$[-]$} \\
\hline \multicolumn{3}{|l|}{ Susceptibility to: } \\
\hline $\begin{array}{l}\text { Nalidixic acid }(30-\mu \mathrm{g} \\
\text { disk) }\end{array}$ & + & - \\
\hline $\begin{array}{l}\text { Cephalothin }(30-\mu \mathrm{g} \\
\text { disk) }\end{array}$ & + & + \\
\hline
\end{tabular}

$a+, 90$ to $100 \%$ of the strains are positive; $d, 26$ to $75 \%$ of the strains are positive; $[-], 11$ to $25 \%$ of the strains are positive;,- 0 to $10 \%$ of the strains are positive.

${ }^{b}$ Other investigators $(7,9)$ have reported that the majority of the $C$. mucosalis strains that they tested, including strain NCTC $11000^{\mathrm{T}}$, reduced nitrite. However, these workers used a different basal medium (nitrate broth supplemented with $5 \%$ inactivated horse serum) than the medium used in the study reported here (brucella broth).

"See reference 18.

Bergey's Manual of Systematic Bacteriology (21) is based on earlier descriptions of this organism $(7,8)$ and does not reflect the discrepancies with the original description that were found during the course of the present study. The results of our DNA homology experiments (Table 2) indicate that $C$. sputorum subsp. mucosalis is a distinct species and is not a subspecies of $C$. sputorum. Therefore, we propose that the name $C$. sputorum subsp. mucosalis be changed to Campylobacter mucosalis comb. nov., and we provide the emended description given below.

Description of Campylobacter mucosalis (Lawson, Leaver, Pettigrew, and Rowland 1981) comb. nov. The following description of Campylobacter mucosalis (mu. co' sal. is. L. n. mucosus mucus; L. gen. n. mucosalis of mucus, pertaining to mucus) is based upon descriptions given by Lawson et al. $(7,9)$ and Smibert (21) and upon observations made during the course of this study. The cells are short, irregularly curved, and gram negative and may appear as spiral forms 0.25 to $0.3 \mu \mathrm{m}$ in diameter and 1 to $3 \mu \mathrm{m}$ long. Motile by means of a single polar flagellum. Coccoid bodies and filamentous forms may be seen in older cultures. Colonies are $1.5 \mathrm{~mm}$ in diameter, circular, and raised with flat surfaces. The colonies have a dirty yellow color that is best seen by smearing a colony on a piece of white paper (9). Requires either hydrogen or formate as an electron donor for growth. Grows under microaerophilic conditions $\left(6 \% \mathrm{O}_{2}, 5 \%\right.$ 
$\mathrm{CO}_{2}, 15 \% \mathrm{H}_{2}, 74 \% \mathrm{~N}_{2}$ ) where $\mathrm{O}_{2}$ serves as the electron acceptor or anaerobically with fumarate as the terminal electron acceptor. Contains appreciable amounts of lauric acid $\left(C_{12}\right)$ in its cellular fatty acids (15). Other phenotypic characteristics of type strain NCTC 11000 and seven other strains are listed in Table 3 .

Isolated from the intestinal mucosa of pigs with porcine intestinal adenomatosis, necrotic enteritis, regional ileitis, and proliferative hemorrhagic enteropathy; also isolated from the oral cavities of pigs.

The $\mathrm{G}+\mathrm{C}$ content of the DNA of type strain NCTC 11000 is $39 \mathrm{~mol} \%$, as calculated by the equation of Mandel et al. (11). The thermal melting point of the DNA is $84.3^{\circ} \mathrm{C}$ in $1 \times$ $\mathrm{SSC}$ buffer $(0.15 \mathrm{M} \mathrm{NaCl}$ plus $0.015 \mathrm{M}$ sodium citrate, $\mathrm{pH}$ 7.0).

C. mucosalis NCTC $11000^{\mathrm{T}}$ shows less than $9 \%$ DNA homology with reference strains of $C$. sputorum subsp. sputorum, C. sputorum subsp. bubulus, C. concisus, Campylobacter fetus subsp. fetus, C. fetus subsp. venerealis, Campylobacter jejuni, Campylobacter coli, C. laridis, C. nitrofigilis, "C. fecalis," and " $C$. hyointestinalis," catalasenegative or weakly catalase-positive strain CG-1, and aerotolerant Campylobacter sp. strain 02790 (Table 2).

\section{ACKNOWLEDGMENTS}

We thank Ella Beaver and Ben Knopp for excellent technical assistance.

\section{LITERATURE CITED}

1. Benjamin, J., S. Leaper, R. J. Owen, and M. B. Skirrow. 1983. Description of Campylobacter laridis, a new species comprising the nalidixic acid resistant thermophilic Campylobacter (NARTC) group. Curr. Microbiol. 8:231-238.

2. Firehammer, B. D. 1965 . The isolation of vibrios from ovine feces. Cornell Vet. 55:482-494.

3. Gebhart, C. J., G. E. Ward, K. Chang, and H. J. Kurtz. 1983. Campylobacter hyointestinalis (new species) isolated from swine with lesions of proliferative ileitis. Am. J. Vet. Res. 44:361-367.

4. George, H. A., P. S. Hoffman, R. M. Smibert, and N. R. Krieg. 1978. Improved media for growth and aerotolerance of Campylobacter fetus. J. Clin. Microbiol. 8:36-41.

5. Hébert, G. A., D. G. Hollis, R. E. Weaver, M. A. Lambert, M. J. Blaser, and C. W. Moss. 1982. 30 years of campylobacters: biochemical characteristics and a biotyping proposal for Campylobacter jejuni. J. Clin. Microbiol. 15:1065-1073.

6. Johnson, J. L. 1981. Genetic characterization, p. 450-472. In P. Gerhardt, R. G. E. Murray, R. N. Costilow, E. W. Nester, W. A. Wood, N. R. Krieg, and G. B. Phillips (ed.), Manual of methods for general bacteriology. American Society for Microbiology, Washington, D.C.

7. Lawson, G. H. K., J. L. Leaver, G. W. Pettigrew, and A. C. Rowland. 1981. Some features of Campylobacter sputorum subsp. mucosalis subsp. nov., nom. rev. and their taxonomic significance. Int. J. Syst. Bacteriol. 31:385-391.

8. Lawson, G. H. K., and A. C. Rowland. 1974. Intestinal adenomatosis in the pig: a bacteriological study. Res. Vet. Sci. 17:331-336.

9. Lawson, G. H. K., and A. C. Rowland. 1984. Campylobacter sputorum subspecies mucosalis, p. 207-225. In J. P. Butzler (ed.), Campylobacter infection in man and animals. CRC Press, Inc., Boca Raton, Fla.

10. Loesche, W. J., R. J. Gibbons, and S. S. Socransky. 1965. Biochemical characteristics of Vibrio sputorum and relationship to Vibrio bubulus and Vibrio fetus. J. Bacteriol. 89:1109-1116.

11. Mandel, M., L. Igambi, J. Bergendahl, M. L. Dodson, Jr., and E. Scheltgen. 1970. Correlation of melting temperature and cesium chloride buoyant density of bacterial deoxyribonucleic acid. J. Bacteriol. 101:333-338.

12. Marmur, J., and P. Doty. 1961. Thermal renaturation of deoxyribonucleic acids. J. Mol. Biol. 3:585-594.

13. Marmur, J., and P. Doty. 1962. Determination of the base composition of deoxyribonucleic acid from its thermal denaturation temperature. J. Mol. Biol. 5:109-118.

14. McClung, C. R., and D. G. Patriquin. 1980. Isolation of a nitrogen-fixing Campylobacter species from the roots of Spartina alterniflora Loisel. Can. J. Microbiol. 26:881-886.

15. Moss, C. W., A. Kai, M. A. Lambert, and C. Patton. 1984. Isoprenoid quinone content and cellular fatty acid composition of Campylobacter species. J. Clin. Microbiol. 19:772-776.

16. Neill, S. D., W. A. Ellis, and J. J. O'Brien. 1979. Designation of aerotolerant campylobacter-like organisms from porcine and bovine abortions to the genus Campylobacter. Res. Vet. Sci. 27:180-186.

17. Owen, R. J., and S. Leaper. 1981. Base composition, size and nucleotide sequence similarities of genome deoxyribonucleic acids from species of the genus Campylobacter. FEMS Microbiol. Lett. 12:395-400.

18. Roop, R. M., II, R. M. Smibert, J. L. Johnson, and N. R. Krieg. 1984. Differential characteristics of catalase-positive campylobacters correlated with DNA homology groups. Can. J. Microbiol. 30:938-951.

19. Sandstedt, K., J. Ursing, and M. Walder. 1983. Thermotolerant Campylobacter with no or weak catalase activity isolated from dogs. Curr. Microbiol. 8:209-213.

20. Selin, Y. M., B. Harich, and J. L. Johnson. 1983. Preparation of labeled nucleic acids (nick translation and iodination) for DNA homology and rRNA hybridization experiments. Curr. Microbiol. 8:127-132.

21. Smibert, R. M. 1984. Genus Campylobacter Sebald and Véron 1963, 907, p. 111-118. In N. R. Krieg and J. G. Holt (ed), Bergey's manual of systematic bacteriology, vol. 1. The Williams \& Wilkins Co., Baltimore.

22. Tanner, A. C. R., S. Badger, C.-H. Lai, M. A. Listgarten, R. A. Visconti, and S. S. Socransky. 1981. Wolinella gen. nov., Wolinella succinogenes (Vibrio succinogenes Wolin et al.) comb. nov., and description of Bacteroides gracilis sp. nov., Wolinella recta sp. nov., Campylobacter concisus sp. nov., and Eikenella corrodens from humans with periodontal disease. Int. J. Syst. Bacteriol. 31:432-445. 